\title{
David Oliver: Ageing, risk, and public perception
}

\author{
David Oliver consultant in geriatrics and acute general medicine
}

Berkshire

In last week's column I discussed some issues raised by the BBC One drama Care. ${ }^{12}$ The show highlighted different perceptions and attitudes about risk and autonomy in older people who have difficulty managing at home.

Hospital staff were portrayed as desperate to get Jenny's mother, Mary (Alison Steadman), back into her home after being disabled by a stroke and cognitive impairment. They clearly saw this as the right thing for Mary and for a system under pressure. But, in Jenny's view, Mary was clearly no longer safe — and short, episodic visits from home care staff, who didn't know her well, wouldn't make her so. A nursing home seemed the least bad option.

In 2014 a BBC Two documentary series, Protecting Our Parents, ${ }^{3}$ covered issues facing frail old people who use health and social care services. A recurring theme was health professionals' belief that they were respecting the wishes of older patients with the capacity to make decisions about ongoing support needs, while acting in the best interests of those who lacked capacity. But the families often seemed surprised, concerned, and even horrified that these patients were allowed to remain at home or return there.

The Times columnist Janice Turner has written regularly about her mother's repeated hospital admissions. ${ }^{4}$ Turner acknowledges that this is often not the best, safest, or most personalised environment and advocates more "halfway house" destinations to allow rest and recuperation before returning home. Yet she sees a repeated race to discharge her mother from hospital as quickly as possible.

Healthwatch England's Safely Home report and its research on emergency readmissions contain many stories of patients feeling marooned in hospital by long waits for social care or stepdown intermediate care, ${ }^{56}$ echoing official figures on delayed transfers from hospital.

Professional guidance tends to assume that any sane patient, if asked, would want to go home

Legal duties and rights, in the form of the Mental Capacity, Human Rights, and Equality acts and professional codes of conduct, require us as professionals to respect older people's decisions and rights and to consider their best interests. ${ }^{7-11} \mathrm{We}$ do so despite concern from families, the media, and wider society about risk. Our professional training emphasises the need to respect patients' choices and not infantilise them. Initiatives such as NHS Improvement's "Red2Green" bed days programme $^{12}$ for improving patient flow emphasise that admission carries its own risks and that we should support any patient's right to accept managed risk and return home.

In my view, much managerialist guidance for professionals ${ }^{13}$ takes insufficient account of carers' needs and views. It also tends to assume that any sane patient, if asked, would want to go home. Clearing beds by ever faster discharge is a holy grail. Admission does carry risks, but it isn't automatically riskier than leaving.

Guidance also fails to acknowledge what Healthwatch has shown - that patients and their families often don't feel ready. Even if they do, the stepdown health and social care capacity to support timely discharge often isn't there. ${ }^{14}{ }^{15}$ And, once a patient is back home, it's not the health and care professionals who are living 24/7 with anxiety, isolation, or at best intermittent support, often from relative strangers on low pay. ${ }^{16}$

I'm not saying that any party has got this entirely right or wrong. But there's often a clear gulf in perception between health professionals' and carers' views of what's best for a patient, and mainstream media are throwing an overdue spotlight on this.

Competing interests: See www.bmj.com/about-bmj/freelance-contributors/davidoliver.

Provenance and peer review: Commissioned; not externally peer reviewed.

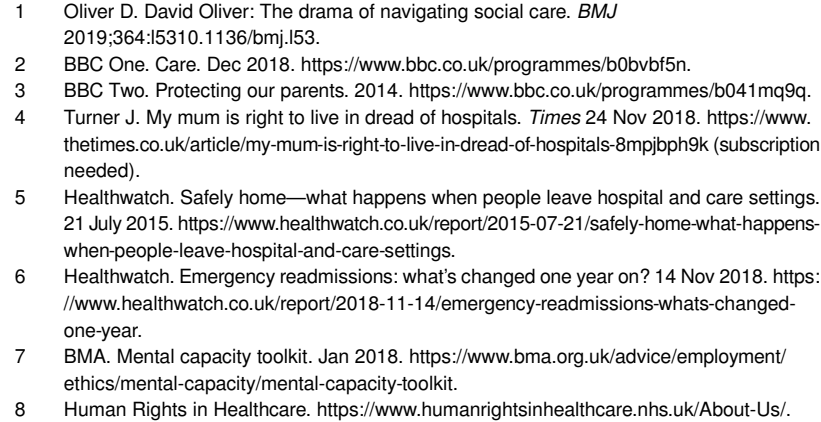

5 Healthwatch. Safely home-what happens when people leave hospital and care settings. 21 July 2015. https:/www.healthwatch.co.uk/report/2015-07-21/safely-home-what-happenswhen-people-leave-hospital-and-care-settings.

6 Healthwatch. Emergency readmissions: what's changed one year on? 14 Nov 2018. https: //www.healthwatch.co.uk/report/2018-11-14/emergency-readmissions-whats-changedone-year.

BMA. Mental capacity toolkit. Jan 2018. https://www.bma.org.uk/advice/employment/ ethics/mental-capacity/mental-capacity-toolkit.

8 Human Rights in Healthcare. https://www.humanrightsinhealthcare.nhs.uk/About-Us/. 
9 Age UK. The Equality Act. https://www.ageuk.org.uk/information-advice/work-learning/ discrimination-rights/the-equality-act/.

10 General Medical Council. The duties of a doctor registered with the General Medical Council. https://www.gmc-uk.org/ethical-guidance/ethical-guidance-for-doctors/goodmedical-practice/duties-of-a-doctor.

11 Nursing and Midwifery Council. The code. 29 Jan 2015. https://www.nmc.org.uk globalassets/sitedocuments/nmc-publications/nmc-code.pdf.

12 NHS Improvement. Red2Green campaign. https://improvement.nhs.uk/improvementoffers/red2green-campaign/.

13 NHS England. Improving hospital discharge. https://www.england.nhs.uk/urgent...care/ hospital-to.../improving-hospital-discharge/.
14 Oliver D. David Oliver: Closing more hospital beds-the policy zombie they couldn't kill. 6 Jan 2017. https://blogs.bmj.com/bmj/2017/01/06/closing-more-hospital-beds-the-policyzombie/.

15 National Audit Office. Discharging older patients from hospital. 26 May 2016. https://www. nao.org.uk/report/discharging-older-patients-from-hospital/.

16 Carers UK. State of caring 2018. July 2018. https://www.carersuk.org/stateofcaring

Published by the BMJ Publishing Group Limited. For permission to use (where not already granted under a licence) please go to http://group.bmj.com/group/rights-licensing/ permissions 